\title{
Assessment of K-struvite precipitation as a means of nutrient recovery from source separated human urine
}

\author{
Işık Kabdaşlı1* Sezen Kuşçuoğlu1 ${ }^{1}$, Olcay Tünay ${ }^{1}$ and Alessio Siciliano²
}

1 Environmental Engineering Department, Civil Engineering Faculty, İstanbul Technical University, Ayazağa Campus; 34469, Sarıyer, İstanbul, Republic of Turkey; sezenk@gmail.com (S.K.); tunayol@itu.edu.tr (O.T.)

2 Laboratory of Environmental Sanitary Engineering, Department of Environmental Engineering, University of Calabria, 87036 Rende (CS), Italy; alessio.siciliano@unical.it (A.S.)

* Correspondence: kabdasli@itu.edu.tr (I.K.); Tel: +90 2122856586

\begin{abstract}
The impact of nutrients on the environment, particularly on water bodies, has led to extensive studies for nutrient control. Within this context, studies have been focused on source separation of human urine from domestic wastewater to recover nutrients. Potassium is one of the most important components of human urine. However, data on potassium removal or recovery are quite limited except for some indirect information through use of zeolites for mostly ammonia removal. Potassium struvite or K-struvite $\left(\mathrm{MgKPO}_{4} \cdot 6 \mathrm{H}_{2} \mathrm{O}\right)$ is a sparingly soluble salt belonging to struvite and has the potential of being used as a means of potassium and phosphate recovery from segregated human urine. This study aimed to assess the potential of K-struvite precipitation for control and recovery of nutrients. Within this context, K-struvite precipitation experiments were performed on both synthetically prepared samples and synthetic human urine solution to determine effect of operation parameters i.e. $\mathrm{pH}$, stoichiometry, and temperature on potassium recovery performance. Results indicated that process performance as well as type of solid phases co-precipitated with Kstruvite were closely related to initial potassium concentration, $\mathrm{pH}$ and reaction stoichiometry. At $\mathrm{pH} 10$, the potassium recovery efficiency was maximized up to $87 \%$ by application of $100 \%$ excess dose of $\mathrm{Mg}$ and $\mathrm{P}$ for both synthetic samples and synthetic human urine solution. On the other hand, application of excess dose of $\mathrm{K}$ did not provide any improvement in K recovery efficiency. The effect of temperature on solubility of K-struvite was insignificant at the temperature of $24-90^{\circ} \mathrm{C}$. Solid phase analyses confirmed that $\mathrm{K}$-struvite was co-precipitated with either $\mathrm{Mg}_{3}\left(\mathrm{PO}_{4}\right)_{2}$, $\mathrm{MgNaPO}_{4} \cdot 7 \mathrm{H}_{2} \mathrm{O}$, or $\mathrm{MgHPO}_{4} \cdot 7 \mathrm{H}_{2} \mathrm{O}$ depending on $\mathrm{pH}$ and stoichiometry instead of a pure compound.
\end{abstract}

Keywords: human urine; K-struvite precipitation; nutrient recovery; operation parameters; solid phases

\section{Introduction}

Magnesium ammonium phosphate $\left(\mathrm{MgNH}_{4} \mathrm{PO}_{4} \cdot 6 \mathrm{H}_{2} \mathrm{O} ; \mathrm{MAP}\right)$, a member of struvite family, has been used with success for nitrogen removal and as a means of nutrient recovery. MAP precipitation has a wide area of application such as source separated urine [14], anaerobic treatment discharge [5], as well as a number of industrial wastewaters among them are leather tanning [6-10], slaughterhouse [11], animal husbandries [12], textile printing [13], landfill leachate [14-16], even membrane process concentrates [17]. This has led to the scientists to the other recoverable nutrient, potassium which is also abundant in source-separated urine. The struvite family of compounds also includes magnesium potassium phosphate (K-struvite), a sparingly soluble salt, which has been considered as a potential method for potassium removal and recovery. Potassium is also a valuable nutrient and can be recovered from the source separated urine [18-20]. MAP precipitation is relatively easy to conduct due to two reasons. The first reason is its low solubility with respect to K-struvite and the second is the two major co-precipitating solids; $\mathrm{Mg}(\mathrm{OH})_{2}$ and $\mathrm{Mg}_{3}\left(\mathrm{PO}_{4}\right)_{2}$ can be avoided at the optimum $\mathrm{pH}$ of around 9.5 of MAP [21]. K- 
struvite precipitation suffers from both higher solubility and unavoidable co-precipitates which make the process a less efficient one with respect to MAP precipitation. Theoretical assessment of the process is not easy, and determination of thermodynamic constants is still on the way. Struvite type of compounds has the general formula of $\mathrm{M}^{2+} \mathrm{N}^{+} x \mathrm{O}_{4} \cdot \mathrm{nH}_{2} \mathrm{O}$, where $\mathrm{M}^{2+}: \mathrm{Mg}$ or $\mathrm{Ca} ; \mathrm{N}^{+}: \mathrm{K}, \mathrm{Rb}, \mathrm{Cs}, \mathrm{Tl}$, or $\mathrm{Na}, \mathrm{NH}_{4}^{+} ; x: \mathrm{P}$ or As, and $\mathrm{n}=6-8$. Additional information about these compounds can be found elsewhere [22-24]. K-struvite $\left(\mathrm{MgKPO}_{4} \cdot 6 \mathrm{H}_{2} \mathrm{O} ; \mathrm{MPP}\right)$ is a member of this family. MPP is also a sparingly soluble salt, but its dissolution is not congruent. Because it cannot be precipitated as a pure compound, but rather as a mixture of other sparingly soluble solids in urine and other sodium containing solutions. For the case of source separated urine co-precipitating solids are MPP and magnesium sodium phosphate $\left(\mathrm{MgNaPO}_{4} \cdot 7 \mathrm{H}_{2} \mathrm{O} ; \mathrm{MSP}\right)$. The exact solubilities of both co-precipitates are not known. For MPP, pKsp values are given as 10.6 [25], 11.7 [26], and $12.2 \pm 0.253$ [27]. These figures exhibit a wide range. For MSP, $\mathrm{Xu}$ and co-workers [27] calculated the pKsp as $11.6 \pm 0.253$ which is within the range of $p K s p$ values of MPP indicating close Ksp values for MPP and MSP. So, they inevitably precipitate together. As the pKsp of MAP 13.26 [28,29], existence of ammonia inhibits the MPP precipitation. Therefore, studies in the literature were conducted on synthetically prepared urine that does not contain ammonia or real urine pre-treated to remove ammonia $[24,27,30,31]$. Warmadewanthi and Lui [32] claimed that magnesium phosphates (Bobierrite, $\mathrm{Mg}_{3}\left(\mathrm{PO}_{4}\right)_{2} \cdot 8 \mathrm{H}_{2} \mathrm{O}$, $\mathrm{pKsp}=25.2$ and tri magnesium phosphate $\mathrm{Mg}_{3}\left(\mathrm{PO}_{4}\right)_{2} \cdot 22 \mathrm{H}_{2} \mathrm{O}$, pKsp= 23.1) were also coprecipitated with MPP. The $\mathrm{pH}$ values over which these solid phases begin to precipitate reported as 12 and 9 for bobierrite and tri magnesium phosphate, respectively. $\mathrm{Xu}$ et al. [24] pointed out $\mathrm{Mg}_{3}\left(\mathrm{PO}_{4}\right)_{2} \cdot 8 \mathrm{H}_{2} \mathrm{O}$ may precipitate after $\mathrm{pH} 10$ and 11 depending on P:K ratio in MAP precipitation. A similar evaluation was made by Lee et al. [21] and Zhang et al. [33] for MAP precipitation. On the other hand, Taylor et al. [25] reported experimental results of MPP precipitation conducted $\mathrm{pH}$ between $10.42-10.87$ where both bobierrite and tri magnesium phosphate co-precipitated. However, no other study of MPP precipitation cited in this paper has shown any evidence of magnesium phosphate precipitation including crystal identification means such as X-ray diffraction (XRD). Thermodynamic models have not included these compounds as well.

So far MPP precipitations have been conducted in mostly in source separated urine, synthetic urine solution except for a study using $1 / 5$ diluted urine, but in a draft tube and baffle reactor [30]. The present study attempts to evaluate K-struvite precipitation using a wide range of initial potassium concentration $(10-250 \mathrm{mM})$ in batch systems with synthetic solutions. The effects of $\mathrm{pH}$, reaction stoichiometry, time and temperature on $\mathrm{K}$ recovery performance were investigated. The applicability of K-struvite precipitation to the synthetic human urine was explored in terms of process performance. Solid phase analyses were also realized.

\section{Materials and Methods}

\subsection{Samples}

Synthetic samples were prepared using $\mathrm{KH}_{2} \mathrm{PO}_{4}$ and $\mathrm{MgCl}_{2} \cdot 6 \mathrm{H}_{2} \mathrm{O}$ and $\mathrm{KOH}$, $\mathrm{NaH}_{2} \mathrm{PO}_{4}$, and $\mathrm{MgCl}_{2} \cdot 6 \mathrm{H}_{2} \mathrm{O}$ for $\mathrm{K}$-struvite precipitation experiments with stoichiometric and excess doses, respectively. While synthetic human urine prepared, urea was excluded from the original recipe given elsewhere $[27,30,34]$. The recipe used in the present study is given in Table S1 (see Supplementary Material). All reagents were of analytical grade and purchased from Sigma-Aldrich Chemicals (USA).

\subsection{Analytical Procedure and Instruments}

Synthetic samples were prepared using $\mathrm{CO}_{2}$-free deionized water as explained in our previous study [35]. All analyses were accomplished as defined in Standard Methods for the Examination of Water and Wastewater [36]. pH was measured with Orion 920A model pH meter. PFP7/C Research Flame Photometer (Jenway ${ }^{\mathrm{TM}}$ ) was used for potassium measurement. Solid phase analyses were made using X-ray diffractometer (XRD; Rigaku Dmax 
2200, Japan) and scanning electron microscopy (SEM; Philips XL30 SFEG). The deionized water was produced by Sartorius Arium 611 - UV Water Purification System (with conductivity of $0.055 \mu \mathrm{S} \mathrm{cm}-1)$.

\subsection{Precipitation Experiments}

500-mL Erlenmeyer flasks with stopper which were equipped with magnetic stirrer to ensure homogenous mixing, were used as precipitation vessels. After reagent addition to $\mathrm{CO}_{2}$-free deionized water, if required, initial $\mathrm{pH}$ values were adjusted under flash-mixing conditions using $\mathrm{NaOH}$ solution (0.1-1 N). During the course of slow-mixing, solution $\mathrm{pH}$ was measured once a day and adjusted when necessary. At the end of MPP precipitation, all samples were filtrated through Sartorius $0.45 \mathrm{~mm}$ membrane filters before analysing.

\subsection{Equilibrium Time and Temperature}

In order to determine the duration (time) needed to reach the equilibrium, the 7-day precipitation and a long duration of one-month equilibrium time results were compared for $250 \mathrm{mM}$ initial concentration at $\mathrm{pH} 9.0$ (Table S2, see Supplementary Material). The differences between two durations were slight indicating that the 7-day equilibrium duration was considered adequate for experimental evaluations. This finding is consistent with the result of $\mathrm{Xu}$ et al. [27]. After one week storage, maximum relative tolerances were measured as $3.2 \%$ and $5.2 \%$ for $\mathrm{P}$ and $\mathrm{K}$, respectively, in their experiments. Based on these data, they assumed that the reaction time required to reach equilibrium was selected as $60 \mathrm{~min}$.

The effect of temperature on solubility of K-struvite and potentially precipitating other solids was also explored through a MPP precipitation conducted at $\mathrm{pH} 9.0$ by employing $333 \mathrm{mM}$ initial dosage of a stoichiometric $\mathrm{K} / \mathrm{Mg} / \mathrm{P}$ solution. This experiment was realized at room temperature $\left(24^{\circ} \mathrm{C}\right), 30^{\circ} \mathrm{C}$, and $90^{\circ} \mathrm{C}$. The results are displayed in Table S3 (see Supplementary Material). As seen from the table, solubilities, or supernatant concentrations after precipitation were almost identical indicating that the effect of temperature was negligible in the range studied. The temperature dependency of magnesium ammonium phosphate (magnesium struvite) has been assessed in the literature and similar results have been found [29]. Based on these data all precipitation experiments were performed in a temperature-controlled laboratory section at $25 \pm 0.1^{\circ} \mathrm{C}$ for a week ensuring equilibrium condition.

\section{Results and discussion}

\subsection{Effect of $p H$}

$\mathrm{pH}$ is one of the key parameters in precipitation processes which involve acid-base reactions. The first experimental evaluation was made using a $250 \mathrm{mM}$ initial concentration with a $\mathrm{K} / \mathrm{Mg} / \mathrm{P}$ molar ratio of $1 / 1 / 1$ to ensure high level of saturation for a wide $\mathrm{pH}$ range of 6 to 11. The results of MPP precipitation performed using $\mathrm{KH}_{2} \mathrm{PO}_{4}$ and $\mathrm{MgCl}_{2} \cdot 6 \mathrm{H}_{2} \mathrm{O}$ as precipitating agents are presented in Table 1.

The results indicated that $\mathrm{K}$ concentration together with $\mathrm{P}$ and $\mathrm{Mg}$ decreased in all experiments with $\mathrm{pH}$ values between 7.03 and 11.00. At $\mathrm{pH}$ 6.06, however, $\mathrm{K}$ concentration remained unchanged, while $\mathrm{P}$ and $\mathrm{Mg}$ concentration significantly reduced from 250 $\mathrm{mM}$ to $16 \mathrm{mM}$. Considering that the formation of MSP was impossible since no $\mathrm{pH}$ adjustment was made using $\mathrm{NaOH}$ during this run, the significant reduction of both $\mathrm{Mg}$ and $\mathrm{P}$ might be attributed to the precipitation of $\mathrm{MgHPO}_{4}$. At $\mathrm{pH} 7.03$, $\mathrm{K}$ removal with precipitation is evident and only K salt precipitating is MPP. The precipitate was assumed to be a mixture of $\mathrm{MgHPO}_{4}$ and $\mathrm{MPP}$ because $\mathrm{K}$ removal was $20 \%$ and $\mathrm{NaOH}$ addition for $\mathrm{pH}$ adjustment was extremely low. Results of precipitation at $\mathrm{pH} 7.99$ could be interpreted in a similar manner as that of 7.03 while MPP precipitation becoming significantly higher as $\mathrm{K}$ removal was $44 \%$. The precipitation conducted at $\mathrm{pH} 9.14$ yielded slightly higher $\mathrm{K}$ removal than that of $\mathrm{pH} 7.99$ indicating almost the same extent of MPP precipitation. 
$\mathrm{MgHPO}_{4}$ even $\mathrm{Mg}(\mathrm{OH})_{2}$ were not likely to precipitate leaving only possibility of MSP. Results of $\mathrm{pH} 10.01$ and $\mathrm{pH} 11.00$ were quite similar with one another and seemed to have similar mechanism with that of $\mathrm{pH} 9.14$, with a small reduction in K recovery efficiency. Although, residual $\mathrm{K}$ concentrations differed, the mechanism depicted above was in accordance with the experimental results of Taylor et al. [25]. Xu et al. [24] in their experimental study with synthetic urine found that $\mathrm{K}$ removal efficiencies decreased after $\mathrm{pH}$ $12, \mathrm{pH} 10$ and 11 yielded efficiencies very close to each other and represented optimum $\mathrm{pH}$ for $\mathrm{K}$ removal. They explained the $\mathrm{K}$ removal efficiency drop at $\mathrm{pH} 12$ with formation of $\mathrm{Mg}(\mathrm{OH})_{2}$ and $\mathrm{Mg}_{3}\left(\mathrm{PO}_{4}\right)_{2}$. Huang et al [31] tested low grade $\mathrm{MgO}$ as a means of $\mathrm{K}$ removal from urine that was pre-treated to remove ammonia. Their experimental data indicated that $\mathrm{K}$ precipitation remained practically unchanged after $\mathrm{pH}$ of approximately 10.7 .

Table 1. Effect of $\mathrm{pH}$ on K-struvite precipitation (K/Mg/P: 250/250/250 mM)

\begin{tabular}{cccccccc}
\hline \multirow{2}{*}{$\mathbf{p H}$} & Unit & \multicolumn{3}{c}{ Initial } & $\mathbf{3}$ & Final \\
\cline { 3 - 8 } & & $\mathbf{K}$ & $\mathbf{P}$ & $\mathbf{M g}$ & $\mathbf{K}$ & $\mathbf{P}$ & $\mathbf{M g}$ \\
\hline \multirow{2}{*}{6.06} & $\mathrm{mM}$ & 250 & 250 & 250 & 248 & 16 & 16 \\
& $\mathrm{mg} / \mathrm{L}$ & 9775 & 7750 & 6076 & 9714 & 520 & 390 \\
7.03 & $\mathrm{mM}$ & 250 & 250 & 250 & 198 & 16 & 5 \\
& $\mathrm{mg} / \mathrm{L}$ & 9775 & 7750 & 6076 & 7772 & 553 & 134 \\
7.99 & $\mathrm{mM}$ & 250 & 250 & 250 & 138 & 7.5 & 8 \\
& $\mathrm{mg} / \mathrm{L}$ & 9775 & 7750 & 6076 & 5399 & 232 & 200 \\
9.14 & $\mathrm{mM}$ & 250 & 250 & 250 & 132 & 5 & 1.5 \\
& $\mathrm{mg} / \mathrm{L}$ & 9775 & 7750 & 6076 & 5366 & 148 & 34 \\
\multirow{3}{*}{10.01} & $\mathrm{mM}$ & 250 & 250 & 250 & 144 & 6 & 1.5 \\
& $\mathrm{mg} / \mathrm{L}$ & 9775 & 7750 & 6076 & 5645 & 189 & 27 \\
\multirow{2}{*}{11.00} & $\mathrm{mM}$ & 250 & 250 & 250 & 147 & 6 & 0.9 \\
& $\mathrm{mg} / \mathrm{L}$ & 9775 & 7750 & 6076 & 5763 & 97 & 24 \\
\hline
\end{tabular}

In the light of the above evaluations, forthcoming MPP precipitation experiments were run within the range of 8-10. In the present paper, we also intentionally avoided to


than one solid phase precipitating. Instead, the term "maximum removal or recovery" could be used which is relative to system composition and aim of the work.

To assess the effect of $\mathrm{pH}$ on $\mathrm{K}$ recovery performance another set of precipitation experiments was run at $\mathrm{pH} 9$ and 10 with an initial concentration of $100 \mathrm{mM}$ equimolar $\mathrm{Mg}$, $\mathrm{K}$, and $\mathrm{P}$, which represented upper concentration of $\mathrm{K}$ in human urine. The results are outlined in Table 2. As seen from the table, while residual $\mathrm{P}$ and $\mathrm{Mg}$ concentrations were similar with those of the experiments with $250 \mathrm{mM}$ initial concentration, resulting $\mathrm{K}$ concentration was lower, $\mathrm{K}$ recovery efficiency was also reduced (at $\mathrm{pH} 9$ dropped from $47 \%$ to $25 \%)$.

Table 2. Effect of $\mathrm{pH}$ on K-struvite recovery (K/Mg/P: 100/100/100 mM)

\begin{tabular}{|c|c|c|c|c|c|c|c|}
\hline \multirow{2}{*}{$\mathrm{pH}$} & \multirow{2}{*}{ Unit } & \multicolumn{3}{|c|}{ Initial } & \multicolumn{3}{|c|}{ Final } \\
\hline & & $\mathbf{K}$ & $\mathbf{P}$ & Mg & $\mathbf{K}$ & $\mathbf{P}$ & $\mathrm{Mg}$ \\
\hline \multirow{2}{*}{9.03} & $\mathrm{mM}$ & 100 & 100 & 100 & 75 & 1.3 & 1.3 \\
\hline & $\mathrm{mg} / \mathrm{L}$ & 3910 & 3100 & 2431 & 2937 & 41 & 32 \\
\hline \multirow{2}{*}{10.05} & $\mathrm{mM}$ & 100 & 100 & 100 & 72 & 0.2 & 6 \\
\hline & $\mathrm{mg} / \mathrm{L}$ & 3910 & 3100 & 2431 & 2812 & 7 & 16 \\
\hline
\end{tabular}


Table 3 displays the results of precipitation experiments initiated at $10 \mathrm{mM}$ stoichiometric dose. As seen in the table, $\mathrm{K}$ recovery efficiencies were maximum $7 \%$ and did not change by $\mathrm{pH}$. Data given in this subsection, altogether indicated that $\mathrm{K}$ recovery efficiencies constantly decreased as initial $\mathrm{K}$ concentration reduced and became practically inapplicable for $10 \mathrm{mM}\left(390 \mathrm{mgK} \mathrm{L}^{-1}\right)$.

Table 3. Effect of $\mathrm{pH}$ on $\mathrm{K}$-struvite recovery (K/Mg/P: 10/10/10 mM)

\begin{tabular}{llllllll}
\hline \multirow{2}{*}{$\mathbf{p H}$} & Unit & \multicolumn{3}{c}{ Initial } & \multicolumn{3}{c}{ Final } \\
\cline { 3 - 8 } & & $\mathbf{K}$ & $\mathbf{P}$ & $\mathbf{M g}$ & $\mathbf{K}$ & $\mathbf{P}$ & $\mathbf{M g}$ \\
\hline \multirow{2}{*}{8.08} & $\mathrm{mM}$ & 10 & 10 & 10 & 9.5 & 4.9 & 0.3 \\
& $\mathrm{mg} / \mathrm{L}$ & 391 & 310 & 243 & 373 & 154 & 0.8 \\
\multirow{2}{*}{9.10} & $\mathrm{mM}$ & 10 & 10 & 10 & 9.3 & 3.4 & 3 \\
& $\mathrm{mg} / \mathrm{L}$ & 391 & 310 & 243 & 367 & 106 & 0.7 \\
\multirow{2}{*}{10.00} & $\mathrm{mM}$ & 10 & 10 & 10 & 9.3 & 2.8 & 2 \\
& $\mathrm{mg} / \mathrm{L}$ & 391 & 310 & 243 & 363 & 88 & 0.5 \\
\hline
\end{tabular}

\subsection{Precipitation with Different Stoichiometry}

To investigate the effect of the reaction stoichiometry on the process performance, MPP precipitation experiments with over-stoichiometric dose were planned and realized. $\mathrm{KOH}, \mathrm{NaH}_{2} \mathrm{PO}_{4}$, and $\mathrm{MgCl}_{2} \cdot 6 \mathrm{H}_{2} \mathrm{O}$ were utilized as reagents in these experiments. In the first step, $\mathrm{K}$ was dosed over stoichiometric to $\mathrm{Mg}$ and $\mathrm{P}$ at the excess $\mathrm{K}$ ratios 20, 34 and $44 \%$. The results are outlined in Table 4 .

Table 4. Effect of excess K dose on process performance

\begin{tabular}{llcccccc}
\hline \multirow{2}{*}{$\mathbf{p H}$} & Unit & \multicolumn{3}{c}{ Initial } & \multicolumn{3}{c}{ Final } \\
\cline { 3 - 8 } & & $\mathbf{K}$ & $\mathbf{P}$ & $\mathbf{M g}$ & $\mathbf{K}$ & $\mathbf{P}$ & $\mathbf{M g}$ \\
\hline \multirow{2}{*}{9.02} & $\mathrm{mM}$ & 180 & 150 & 150 & 121 & 1.65 & 1.6 \\
& $\mathrm{mg} / \mathrm{L}$ & 7038 & 4650 & 3646 & 4731 & 50 & 40 \\
9.02 & $\mathrm{mM}$ & 180 & 125 & 125 & 112 & 2.4 & 1.3 \\
& $\mathrm{mg} / \mathrm{L}$ & 7038 & 3875 & 3038 & 4379 & 74 & 32 \\
& $\mathrm{mM}$ & 250 & 187 & 187 & 190 & 2.2 & 0.9 \\
& $\mathrm{mg} / \mathrm{L}$ & 9775 & 5797 & 4545 & 7429 & 68 & 22 \\
\hline
\end{tabular}

As seen in Table 4, for 125 and $150 \mathrm{mM}$ doses of $\mathrm{Mg}$ and $\mathrm{P}$, application of $180 \mathrm{mM} \mathrm{K}$ resulted in very low residual $\mathrm{P}$ and $\mathrm{Mg}$ levels. $\mathrm{K}$ removals were limited to 32 and $37 \%$ for 150 and $125 \mathrm{mM}$ doses, respectively, exhibiting much less than $\mathrm{KMgPO}_{4}$ stoichiometry. For a $\mathrm{K}$ dose of $250 \mathrm{mM}, \mathrm{P}$ and $\mathrm{Mg}$ levels were again low, but $\mathrm{K}$ removal was at $24 \%$ and the residual amount at $190 \mathrm{mM}$, whereas it was $132 \mathrm{mM}$ for $250 \mathrm{mM}$ stoichiometric (K/Mg/P: 1/1/1) dosing at $\mathrm{pH} 9.14$ (Table 1). These results indicate that overdose of $\mathrm{K}$ was ineffective in controlling and improving the $\mathrm{K}$ recovery performance.

In the second step, the effect of overdoses of $\mathrm{Mg}$ and $\mathrm{P}$ on $\mathrm{K}$ recovery efficiency was explored at $\mathrm{pH}$ values of 9 and/or 10. Table 5 shows the results of these experiments. For $180 \mathrm{mM}$ K concentration, increasing both $\mathrm{Mg}$ and P doses from 187.5 to $250 \mathrm{mM}$ improved $\mathrm{K}$ recovery efficiency from $24 \%$ to $50 \%$. The improvement in $\mathrm{K}$ recovery efficiency was also evident at $100 \%$ overdoses of $\mathrm{P}$ and $\mathrm{Mg}$ for a wide range of initial $\mathrm{K}$ concentration from 6.25 to $125 \mathrm{mM}$. The maximum $\mathrm{K}$ recovery was obtained as $85 \%$ with $100 \mathrm{mM} \mathrm{K}$ concentration at $\mathrm{pH} 10.02$. Comparison $\mathrm{K}$ recovery efficiencies obtained at $\mathrm{pH} 9$ with those of $\mathrm{pH} 10$ showed that using $\mathrm{pH} 10$ seemed more effective to enhance $\mathrm{K}$ recovery. Furthermore, in all experiments, residual $\mathrm{Mg}$ and $\mathrm{P}$ values were very low indicating simultaneous 
precipitation of magnesium phosphate solids. Therefore, over stoichiometric $\mathrm{Mg}$ and $\mathrm{P}$ application would help $\mathrm{K}$ recovery without an increase in residual $\mathrm{Mg}$ and $\mathrm{P}$.

Table 5. Results of precipitation experiments at overdoses of $\mathrm{Mg}$ and $\mathrm{P}$

\begin{tabular}{|c|c|c|c|c|c|c|c|}
\hline \multirow{2}{*}{$\mathrm{pH}$} & & \multicolumn{3}{|c|}{ Initial } & \multicolumn{3}{|c|}{ Final } \\
\hline & & $\mathbf{K}$ & $\mathbf{P}$ & $\mathrm{Mg}$ & $\mathbf{K}$ & $\mathbf{P}$ & Mg \\
\hline \multirow{2}{*}{9.09} & $\mathrm{mM}$ & 180 & 187.5 & 187.5 & 135 & 1.9 & 1.4 \\
\hline & $\mathrm{mg} / \mathrm{L}$ & 7038 & 5813 & 4557 & 5278 & 59 & 34 \\
\hline \multirow{2}{*}{9.07} & $\mathrm{mM}$ & 180 & 250 & 250 & 90 & 0.4 & 4 \\
\hline & $\mathrm{mg} / \mathrm{L}$ & 7038 & 7750 & 6076 & 3519 & 12 & 97 \\
\hline \multirow{2}{*}{9.07} & $\mathrm{mM}$ & 125 & 250 & 250 & 41 & 0.9 & 3 \\
\hline & $\mathrm{mg} / \mathrm{L}$ & 4887 & 7750 & 6076 & 1603 & 28 & 73 \\
\hline \multirow{2}{*}{9.00} & $\mathrm{mM}$ & 50 & 100 & 100 & 17 & 1.9 & 2 \\
\hline & $\mathrm{mg} / \mathrm{L}$ & 1955 & 3100 & 2431 & 686 & 59 & 51 \\
\hline \multirow{2}{*}{10.03} & $\mathrm{mM}$ & 125 & 250 & 250 & 38 & 3 & 0.6 \\
\hline & $\mathrm{mg} / \mathrm{L}$ & 4887 & 7750 & 6076 & 1486 & 93 & 15 \\
\hline \multirow{2}{*}{10.02} & $\mathrm{mM}$ & 100 & 200 & 200 & 15 & 0.2 & 1.5 \\
\hline & $\mathrm{mg} / \mathrm{L}$ & 3901 & 6200 & 4861 & 578 & 8 & 36 \\
\hline \multirow{2}{*}{10.02} & $\mathrm{mM}$ & 50 & 100 & 100 & 11 & 0.2 & 1.4 \\
\hline & $\mathrm{mg} / \mathrm{L}$ & 1955 & 3100 & 2431 & 441 & 6 & 34 \\
\hline \multirow{2}{*}{10.11} & $\mathrm{mM}$ & 25 & 50 & 50 & 7 & 0.8 & 1.3 \\
\hline & $\mathrm{mg} / \mathrm{L}$ & 977 & 1550 & 1215 & 276 & 24 & 32 \\
\hline \multirow{2}{*}{10.08} & $\mathrm{mM}$ & 12.5 & 25 & 25 & 6 & 1 & 1.2 \\
\hline & $\mathrm{mg} / \mathrm{L}$ & 489 & 775 & 608 & 254 & 31 & 29 \\
\hline \multirow{2}{*}{10.12} & $\mathrm{mM}$ & 6.25 & 12.5 & 12.5 & 5 & 1.9 & 1.2 \\
\hline & $\mathrm{mg} / \mathrm{L}$ & 244 & 387 & 303 & 176 & 57 & 30 \\
\hline
\end{tabular}

\subsection{Dissolution of Precipitate}

To determine the components and their composition of the precipitate produced in the experiments, a selected solid phase (obtained from the experiment run at $250 \mathrm{mM}$ stoichiometric doses of K/Mg/P and $\mathrm{pH} 9.0$ ) was completely dissolved in acid. The amount of solid dissolved was $8 \mathrm{gL}^{-1}$. The composition of the obtained solution was found as shown in Table 6.

Table 6. Composition of precipitate

\begin{tabular}{lllll}
\hline & $\mathbf{K}$ & $\mathbf{P O}_{4}$ & $\mathbf{M g}$ & $\mathbf{N a}$ \\
\hline $\mathrm{mM}$ & 6.5 & 19 & 19 & 7 \\
\hline
\end{tabular}

The results clearly showed that amount of $\mathrm{P}$ and $\mathrm{Mg}$ were several folds greater than $\mathrm{K}$ indicating high amount of magnesium phosphate contributed to the solid. Existence of sodium was almost equal amount of $\mathrm{K}$ suggested the presence of a sodium containing solid which was likely to be MSP [37]. The obtained solid phase stoichiometry is $\mathrm{Mg} / \mathrm{K} / \mathrm{Na} / \mathrm{P}: 2.9 / 1 / 1.01 / 2.9$ and the stoichiometry of both MSP and MPP is $2 / 1 / 1 / 2$. This finding gives the impression as if the solid phase comprised a mixture of MSP, MPP and some magnesium phosphates. 


\subsection{Potassium Recovery from Human Urine}

Human urine is the principal source for potassium recovery using K-struvite precipitation. Therefore, we also conducted precipitation experiments on synthetic human urine (SHU) defined in the Materials and Methods section. Considering the findings in the relevant literature $[24,27,30,38]$ that ammonia removal by a suitable process, such as stripping, prior to K-struvite precipitation is an essential step so as to enhance $\mathrm{K}$ recovery from SHU solutions, urea was not added to the SHU solution to avoid MAP precipitation. So, the main reactive species of $\mathrm{SHU}$ were $\mathrm{K}, \mathrm{Mg}$ and $\mathrm{P}$. The results obtained from our experimental study and their interpretation strongly suggested that in a such system the solid phase would be composed of a mixture of different substances. Therefore, different stoichiometric doses were employed in these precipitation experiments. The obtained results are given in Table 7.

Table 7. Results of K-struvite precipitation for SHU solution

\begin{tabular}{|c|c|c|c|c|c|c|c|}
\hline \multirow[b]{2}{*}{$\mathrm{pH}$} & \multirow[b]{2}{*}{ K:Mg:P } & & \multicolumn{3}{|c|}{ Initial } & \multicolumn{2}{|c|}{ Final } \\
\hline & & & K & $\mathbf{P}$ & Mg & K & $\mathbf{P}$ \\
\hline \multirow{2}{*}{9.40} & \multirow{2}{*}{ 3/1/0.5 } & $\mathrm{mM}$ & 31.82 & 10.32 & 5.16 & 23 & 3.44 \\
\hline & & $\mathrm{mg} / \mathrm{L}$ & 1244 & 319 & 125 & 920 & 106 \\
\hline \multirow{2}{*}{9.42} & \multirow{2}{*}{$3 / 1 / 1$} & $\mathrm{mM}$ & 31.82 & 10.32 & 10.32 & 24 & 0,99 \\
\hline & & $\mathrm{mg} / \mathrm{L}$ & 1244 & 319 & 251 & 954 & 29 \\
\hline \multirow{2}{*}{9.39} & \multirow{2}{*}{ 3/1/1.3 } & $\mathrm{mM}$ & 31.82 & 10.32 & 13.41 & 24 & 0.36 \\
\hline & & $\mathrm{mg} / \mathrm{L}$ & 1244 & 319 & 326 & 953 & 11 \\
\hline \multirow{2}{*}{9.44} & \multirow{2}{*}{ 3/1/1.5 } & $\mathrm{mM}$ & 31.82 & 10.32 & 15.48 & 25 & 0.14 \\
\hline & & $\mathrm{mg} / \mathrm{L}$ & 1244 & 319 & 376 & 988 & 4 \\
\hline \multirow{2}{*}{9.48} & \multirow{2}{*}{$1 / 1 / 1$} & $\mathrm{mM}$ & 31.82 & 31.82 & 31.82 & 25 & 0.01 \\
\hline & & $\mathrm{mg} / \mathrm{L}$ & 1244 & 986 & 773 & 989 & 1 \\
\hline \multirow{2}{*}{9.44} & \multirow{2}{*}{$1 / 2 / 2$} & $\mathrm{mM}$ & 31.82 & 63.64 & 63.64 & 11 & 9.67 \\
\hline & & $\mathrm{mg} / \mathrm{L}$ & 1244 & 1972 & 1547 & 441 & 300 \\
\hline \multirow{2}{*}{10.04} & \multirow{2}{*}{$1 / 2 / 2$} & $\mathrm{mM}$ & 31.82 & 63.64 & 63.64 & 4 & 4.78 \\
\hline & & $\mathrm{mg} / \mathrm{L}$ & 1244 & 1972 & 1547 & 167 & 147 \\
\hline
\end{tabular}

As seen in Table 7, the best result, through the experiments conducted using SHU solution with initial $\mathrm{K}$ concentration of $31.82 \mathrm{mM}$, was obtained as $87 \% \mathrm{~K}$ recovery with $\mathrm{K} / \mathrm{Mg} / \mathrm{P}$ ratio of $1 / 2 / 2$ and at $\mathrm{pH} 10.04$. With the same stoichiometry, but at $\mathrm{pH} 9.44, \mathrm{~K}$ recovery $(67 \%)$ as well as $\mathrm{P}$ removal decreased. These $\mathrm{K}$ recovery efficiencies are comparable with data published in the literature. For example, ammonium, $\mathrm{K}$, and $\mathrm{P}$ removals were reported as $73 \%, 76 \%$, and $68 \%$, respectively, in Xu et al. [30] study performed on ammonia stripped-diluted (1/5) real human urine in a laboratory-scale draft tube and baffle reactor. In another study, conducted in a pilot-scale fluidized bed reactor using SHU (recipe: $30.9 \mathrm{mM} \mathrm{KH} 2 \mathrm{PO}_{4}, 21 \mathrm{mM} \mathrm{KCl}, 0.7 \mathrm{mM} \mathrm{CaCl} \cdot 2 \mathrm{H}_{2} \mathrm{O}, 78.7 \mathrm{mM} \mathrm{NaCl}, 16.2 \mathrm{mM}$ $\mathrm{Na}_{2} \mathrm{SO}_{4}$, and $2.86 \mathrm{mM} \mathrm{NH}_{4} \mathrm{Cl}$ ), for optimized operation conditions of $\mathrm{pH}$ of 10.5, Mg:P molar ratio of 1:1, super saturation ratio of 3.0, and superficial velocity of $350 \mathrm{~cm} \mathrm{~min}^{-1}, \mathrm{~K}$ and $\mathrm{P}$ removal efficiencies were reported as $20-35 \%$ and $80-90 \%$, respectively [38]. This K removal efficiency is the same level with that of the precipitation experiment conducted at $\mathrm{pH} 9.48$ with the $\mathrm{K} / \mathrm{Mg} / \mathrm{P}$ stoichiometry of $1 / 1 / 1$. 


\subsection{Solid phase analyses}

Further studies were conducted to assess the solid phases that were formed through the K-struvite precipitation. Within the context, three selected solid phases were analysed using x-ray diffraction (XRD) method (Fig. S1-S3, see Supplementary Material). The first solid phase was the one obtained from the precipitation at $\mathrm{pH} 10.05$ with stoichiometric dose $(\mathrm{K} / \mathrm{Mg} / \mathrm{P}: 1 / 1 / 1)$ for an initial $\mathrm{K}$ concentration of $100 \mathrm{mM}$. The result indicated the existence of magnesium phosphate and consistent with the discussion of this experiment as well as with the experimental evaluation given by Taylor et al. [25]. Other solid phases analysed using XRD were the precipitates that resulted from the experiments at the $\mathrm{pH} 10$ with the applications of over-stoichiometric (K/Mg/P: 125/250/250 mM) and stoichiometric (250/250/250 mM) Mg and P doses. Examination of these results showed that the existence of sodium in the solid rather than magnesium phosphate implying the structure of MSP as pointed out in the relevant literature $[24,27,30]$.

Scanning electron microscope (SEM) photographs of solid phases obtained through the experiments were used to evaluate the morphology of the precipitates (Figure 1)
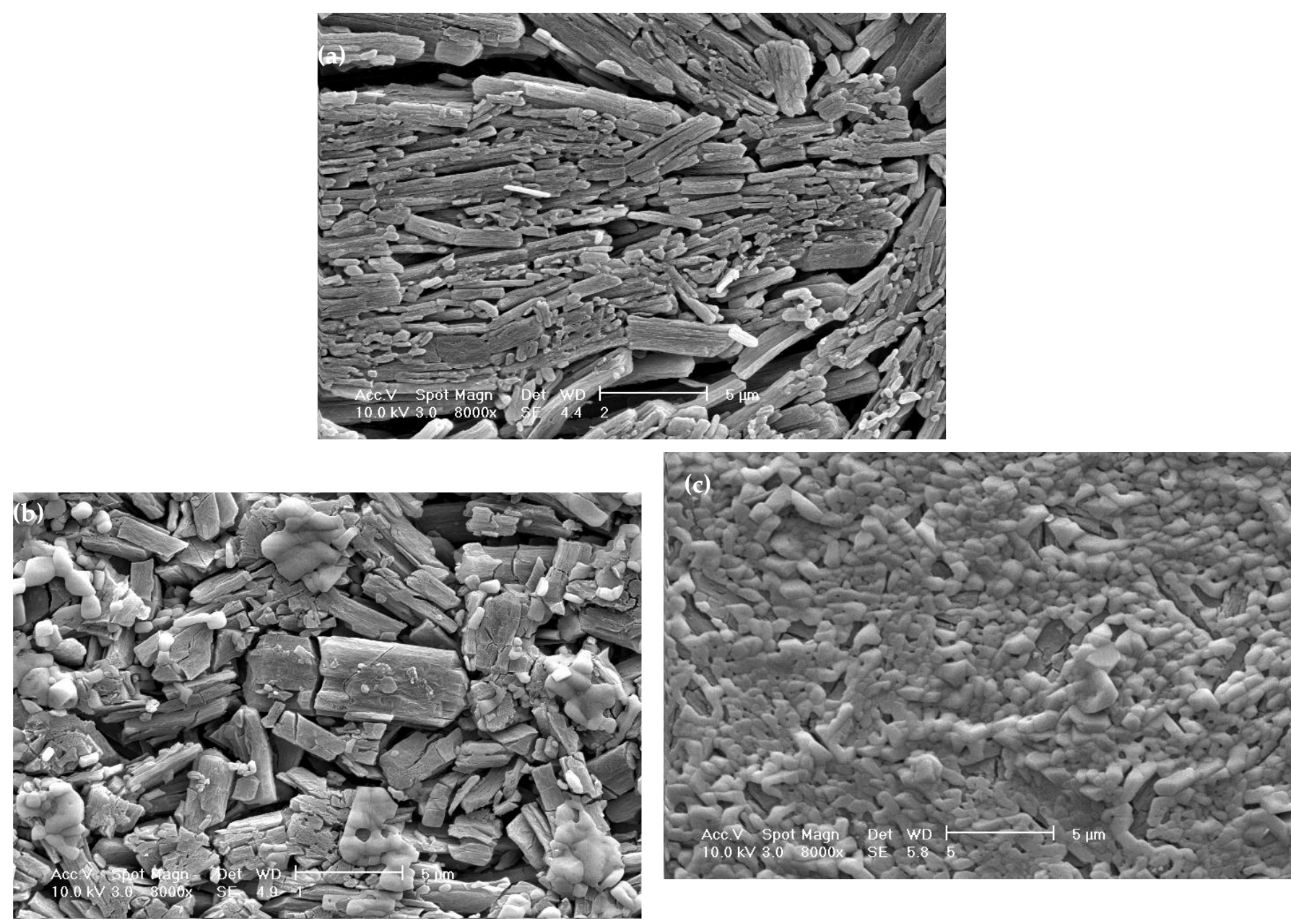

Figure 1. SEM analyses of solid products obtained from precipitation experiments performed at (a) $\mathrm{pH} 9.14 \mathrm{and} \mathrm{K/Mg} / \mathrm{P}: 250 / 250 / 250$ mM, (b) pH 10.05 and K/Mg/P: 100/100/100 mM, and (c) pH 10.03 and K/Mg/P: 125/250/250 mM.

In Figure 1 (a) K-struvite crystals can be clearly seen as a similar structure with that of MAP having long needle like shape. In Figure 1 (b) magnesium phosphate crystals with their spherical shape and together with K-struvite can be observed. Their size was irregular. In the case of overdose of $\mathrm{Mg}$ and $\mathrm{P}$ a mixture of crystals each having different structure was noticed (Figure 1(c)). 


\title{
4. Conclusions
}

The following conclusions could be drawn from the present study.

$\checkmark$ In the case of synthetic samples, K recovery efficiency found to be dependent on initial $\mathrm{K}$ concentration, reaction stoichiometry and $\mathrm{pH}$.

$\checkmark \quad \mathrm{K}$ recovery efficiencies reduced while initial K concentration decreased. The lowest $\mathrm{K}$ recovery efficiency $(7 \%)$ was obtained for initial $\mathrm{K}$ concentration of $390 \mathrm{mg} \mathrm{K} \mathrm{L}^{-1}$ at stoichiometric dose. For a wide range of initial $\mathrm{K}$ concentration of 6.25 to $125 \mathrm{mM}, \mathrm{K}$ recovery efficiency improved when applied $100 \%$ excess doses of $\mathrm{P}$ and $\mathrm{Mg}$ to $\mathrm{K}$. On the other hand, excess dose of $\mathrm{K}$ found to be incapable of improving $\mathrm{K}$ recovery performance.

$\checkmark \quad 100 \%$ excess dose of $\mathrm{Mg}$ and $\mathrm{P}(\mathrm{K} / \mathrm{Mg} / \mathrm{P}: 100 / 200 / 200 \mathrm{Mm})$ yielded $\mathrm{K}$ recovery efficiency of $85 \%$ corresponding to a maximum one for synthetic samples at $\mathrm{pH}$ 10.02. Almost equal K recovery efficiency (87\%) was also obtained for synthetic human urine at $\mathrm{pH} 10.04$ and $100 \%$ excess dose of $\mathrm{Mg}$ and $\mathrm{P}$.

$\checkmark \quad$ In all these precipitation experiments performed using synthetically prepared samples, $\mathrm{P}$ and $\mathrm{Mg}$ were almost completely precipitated, resulting the effluents with low $\mathrm{Mg}$ and $\mathrm{P}$ contents.

$\checkmark$ The results indicated that K-struvite never precipitated alone, but its precipitation was accompanied by other solids which, as evidenced by XRD results as well as stoichiometric evaluation of the composition of dissolution of solids, were $\mathrm{Mg}_{3}\left(\mathrm{PO}_{4}\right)_{2}, \mathrm{MgNaPO}_{4} \cdot 7 \mathrm{H}_{2} \mathrm{O}$, and $\mathrm{MgHPO}_{4} \cdot 7 \mathrm{H}_{2} \mathrm{O}$.

\begin{abstract}
Supplementary Materials: The following are available online at www.mdpi.com/xxx/s1, Table S1: Recipe of synthetic human urine used in this study [34], Table S2: Effect of duration on K-struvite precipitation performance, Table S3: Effect of temperature on K-struvite precipitation performance, Figure S1: XRD analysis (K/Mg/P: 250/250/250 mM, pH 10.01), Figure S2: XRD analysis (K/Mg/P: 125/250/250 mM, pH 10.03), Figure S3: XRD analysis (K/Mg/P: 100/100/100 mM, $\mathrm{pH}$ 10.05).
\end{abstract}

Author Contributions: Conceptualization, I.K. and O.T.; methodology, I.K. and O.T.; supervision, I.K.; experimental study- data production, S.K.; writing - review and editing, I.K., O.T. and A.S., All authors have read and agreed to the published version of the manuscript.

Funding: This research was funded by İstanbul Technical University under Project Number BAP32436 .

Conflicts of Interest: The authors declare no conflict of interest.

\section{References}

1. Kabdasli, I.; Tunay, O.; Islek, C.; Erdinc, E.; Huskalar, S.; Tatli, M.B. Nitrogen recovery by urea hydrolysis and struvite precipitation from anthropogenic urine. Water Science and Technology 2006, 53, 305-312, doi:10.2166/wst.2006.433.

2. Kabdasli, I.; Tunay, O.; Udert, K.M. Transfer into the solid phase. Source Separation and Decentralization for Wastewater Management 2013, 351-365.

3. Kabdasli, I.; Tunay, O.; Tatli, B.M.; Topcuoglu, S. Nitrogen recovery by struvite precipitation from anthropogenic nutrient solution. Fresenius Environmental Bulletin 2006, 15, 1146-1149.

4. Tünay, O., Kabdaşlı, I.; Tatlı M.B. Nitrogen removal and recovery from human urine by struvite precipitation. Int. J. Environment and Waste Management 2009, 3, 382-392.

5. Lorick, D.; Macura, B.; Ahlstrom, M.; Grimvall, A.; Harder, R. Effectiveness of struvite precipitation and ammonia stripping for recovery of phosphorus and nitrogen from anaerobic digestate: a systematic review. Environmental Evidence 2020, 9, doi:10.1186/s13750-020-00211-x. 
6. Kabdasli, I.; Tunay, O.; Cetin, M.S.; Olmez, T. Assessment of magnesium ammonium phosphate precipitation for the treatment of leather tanning industry wastewaters. Water Science and Technology 2002, 46, 231-239.

7. Tunay, O.; Kabdasli, I.; Orhon, D.; Kolcak, S. Ammonia removal by magnesium ammonium phosphate precipitation in industrial wastewaters. Water Science and Technology 1997, 36, 225-228, doi:10.1016/s0273-1223(97)00391-0.

8. Zengin, G.; Olmez, T.; Dogruel, S.; Kabdasli, I.; Tunay, O. Assessment of source-based nitrogen removal alternatives in leather tanning industry wastewater. Water Science and Technology 2002, 45, 205-215, doi:10.2166/wst.2002.0428.

9. Tunay, O.; Yelmez, Z.B.; Olmez, T.; Kabdasli, I. Residual COD reduction in biologically treated leather tanning effluents by advanced treatment processes. Journal of the American Leather Chemists Association 2006, 101, 123-131.

10. Kabdasli, I.; Olmez, T.; Tunay, O. Nitrogen removal from tannery wastewater by protein recovery. Water Science and Technology 2003, 48, 215-223, doi:10.2166/wst.2003.0058.

11. Kabdasli, I.; Tunay, O.; Ozcan, P. Application of struvite precipitation coupled with biological treatment to slaughterhouse wastewaters. Environmental Technology 2009, 30, 1095-1101, doi:10.1080/09593330903136856.

12. Huang, H.M.; Xiao, D.A.; Liu, J.H.; Hou, L.; Ding, L. Recovery and removal of nutrients from swine wastewater by using a novel integrated reactor for struvite decomposition and recycling. Scientific Reports 2015, 5, doi:10.1038/srep10183.

13. Kabdaş1, I.; Gürel, M.; Tünay, O. Characterization and treatment of textile printing wastewaters. Environmental Technology 2000, 21, 1147-1155, doi:10.1080/09593330.2000.9619001.

14. Kabdasli, I.; Safak, A.; Tunay, O. Bench-scale evaluation of treatment schemes incorporating struvite precipitation for young landfill leachate. Waste Management 2008, 28, 2386-2392, doi:10.1016/j.wasman.2007.10.020.

15. Zhang, T.; Ding, L.L.; Ren, H.Q. Pretreatment of ammonium removal from landfill leachate by chemical precipitation. Journal of Hazardous Materials 2009, 166, 911-915, doi:10.1016/j.jhazmat.2008.11.101.

16. Kabdasli, I.; Tunay, O.; Ozturk, I.; Yilmaz, S.; Arikan, O. Ammonia removal from young landfill leachate by magnesium ammonium phosphate precipitation and air stripping. Water Science and Technology 2000, 41, 237-240, doi:10.2166/wst.2000.0034.

17. Arola, K.; Van der Bruggen, B.; Manttari, M.; Kallioinen, M. Treatment options for nanofiltration and reverse osmosis concentrates from municipal wastewater treatment: A review. Critical Reviews in Environmental Science and Technology 2019, 49, 2049-2116, doi:10.1080/10643389.2019.1594519.

18. Kabdaşl1, I.; Sertaç, B.; Tünay, O. Nutrient removal from human urine by chemical precipitation. Fresenius Environmental Bulletin 2019, 28, 852-856.

19. Kuşcuoğlu, S. Determination of K-struvite Application Bases. İstanbul Technical University, İstanbul, 2008.

20. Sertaç, B. Recovery of Nitrogen and Phosphorous Removal from Source-Separated Human Urine by Chemical Precipitation. İstanbul Technical University, İstanbul, 2012.

21. Lee, S.I.; Weon, S.Y.; Lee, C.W.; Koopman, B. Removal of nitrogen and phosphate from wastewater by addition of bittern. Chemosphere 2003, 51, 265-271, doi:10.1016/s0045-6535(02)00807-x. 
22. Siciliano, A.; Limonti, C.; Curcio, G.M.; Molinari, R. Advances in Struvite Precipitation Technologies for Nutrients Removal and Recovery from Aqueous Waste and Wastewater. Sustainability 2020, 12, doi:10.3390/su12187538.

23. Tansel, B.; Lunn, G.; Monje, O. Struvite formation and decomposition characteristics for ammonia and phosphorus recovery: A review of magnesium-ammonia-phosphate interactions. Chemosphere 2018, 194, 504-514, doi:10.1016/j.chemosphere.2017.12.004.

24. Xu, K.N.; Wang, C.W.; Liu, H.Y.; Qian, Y. Simultaneous removal of phosphorus and potassium from synthetic urine through the precipitation of magnesium potassium phosphate hexahydrate. Chemosphere 2011, 84, 207-212, doi:10.1016/j.chemosphere.2011.04.057.

25. Taylor, A.W.; Frazier, A.W.; Gurney, E.L. Solubility products of magnesium ammonium and magnesium potassium phosphates. 1963, 59, 1580-1584.

26. Luff, B.B.; Reed, R.B. THERMODYNAMIC PROPERTIES OF MAGNESIUM POTASSIUM ORTHO-PHOSPHATE HEXAHYDRATE. Journal of Chemical and Engineering Data 1980, 25, 310-312, doi:10.1021/je60087a028.

27. Xu, K.N.; Li, J.Y.; Zheng, M.; Zhang, C.; Xie, T.; Wang, C.W. The precipitation of magnesium potassium phosphate hexahydrate for $\mathrm{P}$ and $\mathrm{K}$ recovery from synthetic urine. Water Research $\mathbf{2 0 1 5}$, 80, 71-79, doi:10.1016/j.watres.2015.05.026.

28. Ohlinger, K.N.; Young, T.M.; Schroeder, E.D. Predicting struvite formation in digestion. Water Research 1998, 32, 3607-3614, doi:10.1016/s0043-1354(98)00123-7.

29. Kabdaşl1, I.; Tünay, O. Nutrient recovery by struvite precipitation, ion exchange and adsorption from source-separated human urine - a review. 2018, 7, 106-138, doi:10.1080/21622515.2018.1473504.

30. Xu, K.N.; Wang, C.W.; Wang, X.X.; Qian, Y. Laboratory experiments on simultaneous removal of K and $\mathrm{P}$ from synthetic and real urine for nutrient recycle by crystallization of magnesium-potassiumphosphate-hexahydrate in a draft tube and baffle reactor. Chemosphere 2012, 88, 219-223, doi:10.1016/j.chemosphere.2012.02.061.

31. Huang, H.M.; Li, J.; Li, B.; Zhang, D.D.; Zhao, N.; Tang, S.F. Comparison of different K-struvite crystallization processes for simultaneous potassium and phosphate recovery from source-separated urine. Science of the Total Environment 2019, 651, 787-795, doi:10.1016/j.scitotenv.2018.09.232.

32. Warmadewanthi; Liu, J.C. Recovery of phosphate and ammonium as struvite from semiconductor wastewater. Separation and Purification Technology 2009, 64, 368-373, doi:10.1016/j.seppur.2008.10.040.

33. Zhang, C.; Chen, Y.G. Simultaneous Nitrogen and Phosphorus Recovery from Sludge-Fermentation Liquid Mixture and Application of the Fermentation Liquid To Enhance Municipal Wastewater Biological Nutrient Removal. Environmental Science \& Technology 2009, 43, 6164-6170, doi:10.1021/es9005948.

34. Wilsenach, J.A.; Schuurbiers, C.A.H.; van Loosdrecht, M.C.M. Phosphate and potassium recovery from source separated urine through struvite precipitation. Water Research 2007, 41, 458-466, doi:10.1016/j.watres.2006.10.014.

35. Kabdasli, I.; Atalay, Z.; Tunay, O. Effect of solution composition on struvite crystallization. Journal of Chemical Technology and Biotechnology 2017, 92, 2921-2928, doi:10.1002/jctb.5310.

36. APHA. Standard Methods for Examination of Water and Wastewater, 21 st ed.; American Public Health Association: USA, 2005.

37. Yang, H.X.; Sun, H.J. Crystal structure of a new phosphate compound, $\mathrm{Mg} 2 \mathrm{KNa}(\mathrm{PO} 4)(2)$ center dot 14H(2)O. Journal of Solid State Chemistry 2004, 177, 2991-2997, doi:10.1016/j.jssc.2004.05.008. 
38. Zhang, C.; Xu, K.N.; Li, J.Y.; Wang, C.W.; Zheng, M. Recovery of Phosphorus and Potassium from Source-Separated Urine Using a Fluidized Bed Reactor: Optimization Operation and Mechanism Modeling. Industrial \& Engineering Chemistry Research 2017, 56, 3033-3039, doi:10.1021/acs.iecr.6b04819. 